\title{
The vegetation of the north-western Orange Free State, South Africa. 2. The D land type
}

\author{
M.S. KOOIJ*, G.J. BREDENKAMP* and G.K. THERON*
}

Keywords: classification, habitat interpretation, plant communities, western Grassland Biome

\author{
ABSTRACT
}

\begin{abstract}
As part of a research programme on the synthesis of the vegetation of the western Grassland Biome, the plant communities of the D) land type of the north-western Orange Free State were investigated. The results of a numerical classification (TWINSPAN) of 59 relevés were refined by Braun-Blanquet procedures. The analyses revealed eight plant communities which may be grouped into (wo major communities. A hierarchical classification. description and ecological interpretation of the plant communities, and an ordination (DECORANA) with associated environmental gradients, are presented.
\end{abstract}

\section{UITTREKSEL}

Die ondersoek na die plantgemeenskappe van die D-landtipe in die noordwestelike Oranje-Vrystaat vorm deel van ' $n$ navorsingsprogram oor die sintese van die plantegroei van die westelike Grasveldbioom. Die resultate van 'n numeriese klassifikasie (TWINSPAN) van 59 relevés is met behulp van Braun-Blanquetprosedures verfyn. Agt plantgemeenskappe wat in (wee hoofgemeenskappe gegroepeer kan word, is onderskei. "n Hiërargiese klassifikasie, beskrywing en ekologiese interpretasie van die plantgemeenskappe en 'n ordening (DECORANA) met geassosieerde omgewingsgradiënte. word verskaf.

\section{INTRODUCTION}

The necessity to identify and describe the major vegetation types and subtypes within the Grassland Biome was stated by Mentis \& Huntley (1982) and Scheepers (1986). ( )ne of the major goals of the vegetation classification and mapping task group of the Grassland Biome Project is to produce a vegetation classification and to map the region on a 1:250(000 scale (Scheepers 1986). As mentioned by Bredenkamp, Joubert \& Bezuidenhout (1989), the first step in the synthesis of the vegetation of the western Grassland Biome, is to create a phytosociological data base for the entire area. Little is known of the vegetation of the northwestern Orange Free State. Scheepers (1975) conducted a semi-detailed survey of the vegetation in the Kroonstad area, and Du Preez (1987) described some woody plant communities from the Vredefort District. The northwestern Orange Free State was therefore identified as a priority area for a phytosociological survey.

Extensive bottomland areas, representing the D land type (Land Type Survey Staff 1984) occur in the northwestern Orange Free State. As the margalitic, vertic, melanic or wet structured fersialitic soils of the D land type are often not ploughed and mainly used as pasture for sheep and game, this land type was chosen for the initial vegetation survey.

\section{THE STUDY AREA}

The study area is situated between $26^{\circ} 00^{\prime}$ and $26^{\circ} 23^{\prime}$ E longitude and $27^{\circ}\left(\mathrm{C}^{\prime}\right.$ and $28^{\circ}\left(\mathrm{O}^{\prime} \mathrm{S}\right.$ latitude, in the Grassland Biome of the north-western Orange Free State (Kooij et al. 199(): 234, fig. 1).

The Db and De map units accommodate land where duplex soils with gleycutanic, pedocutanic and prisma-

\footnotetext{
* Department of Botany, University of Pretoria, (0)(0)2, Pretoria MS. received: 1989.09 .07
}

cutanic B horizons are predominant. These map units comprise approximately 280000 ha of the study area, with approximately 35700 ha unsuitable for agriculture (Land Type Survey Staff 1984). Soils that display a duplex character include the Estcourt, Sterkspruit, Swartland, Valsrivier and Kroonstad Forms (MacVicar et al. 1977). The Dc and Db map units are mostly located in bottomland situations, such as in the valleys of the Vaal, Vals and Renoster Rivers, as well as in the Pan Veld situated in the Wesselsbron and Welkom Districts. These map units are not suitable for agronomy, due to the high clay $(>35 \%)$ content of these bottomland soils, and land use is mainly restricted to sheep farming. The bottomlands are furthermore usually flooded during the rainy season.

The Db map unit refers to land where duplex soils with non-red B horizons comprise more than half of the area. The De map unit indicates land that qualifies for inclusion in the D land type but, in addition to the duplex soils, more than $10 \%$ of the land type comprise soil forms with one or more of the following diagnostic horizons: vertic, melanic or red-structured (Land Type Survey Staff 1984). The geology of the Db map unit consists mainly of Ecca sandstone, shale and mudstone with the sporadic intrusion of dolerite sills. Mudstone, shale and sandstone of the Tarkastad Subgroup occur in the eastern parts.

The Dc map unit representing the Pan Veld in the Wesselsbron District consists mainly of the Sterkspruit Form, whereas the soils of the Dc map unit in the vicinity of the Vredefort Dome, mainly represents the Bonheim Form. Pans occupy approximately $22 \%$ of this map unit. The predominant geology of the area is Ecca sandstone, mudstone and shale with the occasional intrusion of dolerite plates. Calcrete occurs sporadically in these bottomland pans. The plains between pans are mostly covered with aeolian sand.

The soils of the Dc map unit adjacent to the rivers are predominantly of the Bonheim and Mayo Forms. The 
TABLE 1. - A phytosociological table of the vegetation of the D land types of the north-western Orange Free State

Communities

1.11 .21 .3
1.4

1.4.1 1.4 .2

Relevés

$\begin{array}{lllllll}101011 & 1100011 & 00100000100 & 000000000100 & 121011112221 & 1100100000\end{array}$ $\begin{array}{llllllllll}581874 & 33 & 58169 & 034157767067 & 445484443233 & 008899990000 & 42151 & 77667\end{array}$

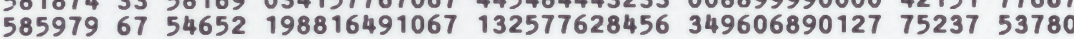

Species group A

Elionurus muticus Setaria sphacelata Hermannia depressa Lippia scaberrima setaria nigrirostris

Digitaria argyrograpta Barleria macrostegia Trichoneura grandiglumis Blephar is integrifolia Vernonia oligocephala Menodora africana

Species group C

Acacia karroo

Protasparagus laricinus Ziziphus mucronata Gomphrena celosioides Commel ina eckloniana Ziziphus zeyheriana Salvia sclarea

Teucrium trifidum

Species group $D$

Hibiscus trionum Seddera capens is Ophioglossum polyphy / I um Sporobolus ludwigi i Blepharis angustata

Species group E

Felicia filifolia Tragus racemosus Mariscus indecorus Sporobolus fimbriatus sporobolus smutsii

Species group F

Geigeria burkei Aristida bipartita Berkheya onopordifolia Indigofera sp. Sporobolus sp.

Aptosimum lineare

Oenothera rosea

Species group G

Conyza sumatrensis Walafrida densiflora Stoebe vulgaris

Stachys spathulata

Marsilea sp.

Eragrost is gummiflua

Echinochloa holubii

Chloris virgata

Species group $H$

Eragrost is plana

Setaria sphacelata

Schkuhria pinnata

Brachiaria serrata

Gazania krebsiana

Schoenoplectus muricinux Haplocarpha scaposa

Species group B

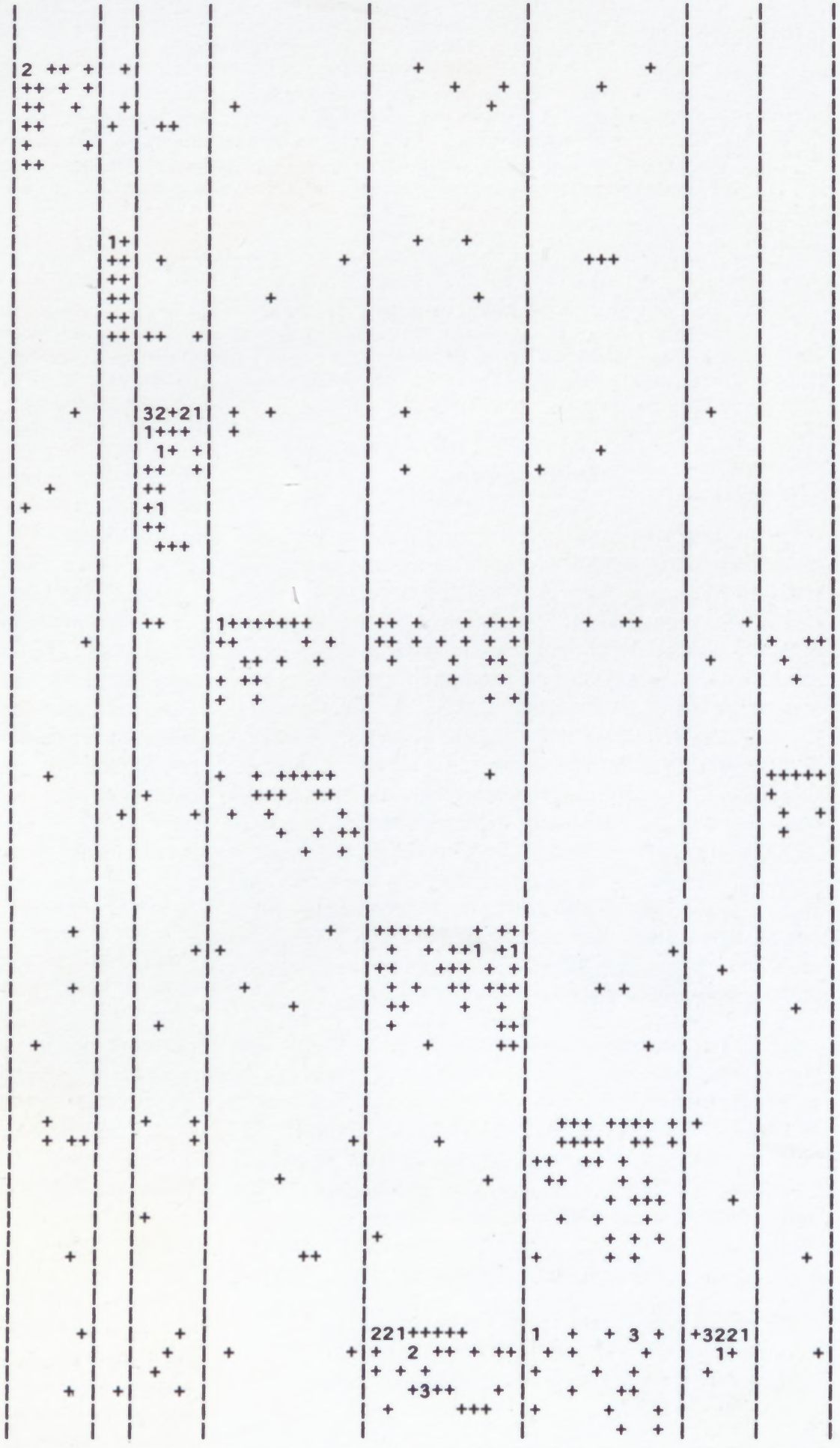

Species with an occurrence of < 4 are omitted. 
Communities
1.4
$1.4 .1 \quad 1.4 .2$
Species group |

\section{Themeda triandra} Felicia muricata Eragrost is superba Cynodon dactylon oxalis sp.

Digitaria eriantha

Cymbopogon plurinodis

Commel ina africana

Chamaesyce prostrata

Cirsium vulgare

Crabbea acaulis

Kyllinga alba

Species group J

Aristida congesta

Corchorus asplenifolius

Heteropogon contortus

Hibiscus pusillus

Ledebouria marginata

Salvia radula

Species group K

Lycium cinereum

Sporobolus ioclados

Pterodiscus speciosus

A l buca sp.

Microchloa caffra

Eragrostis lehmanniana

Eragrostis stapfi i

Mollugo cerviana

Species group L

Panicum coloratum Pentzia globosa

Eragrostis curvula

Eragrost is obtusa

Bulbine narcissifolia

Species group $M$

Berkheya radula

Conyza podocephala

Vahlia capensis

Anthericum galpini

Scabiosa columbaria

Crassula schimperi

Solanum incanum

Iragus berteronianus

Salsola calluna

Asclepias fruticosa

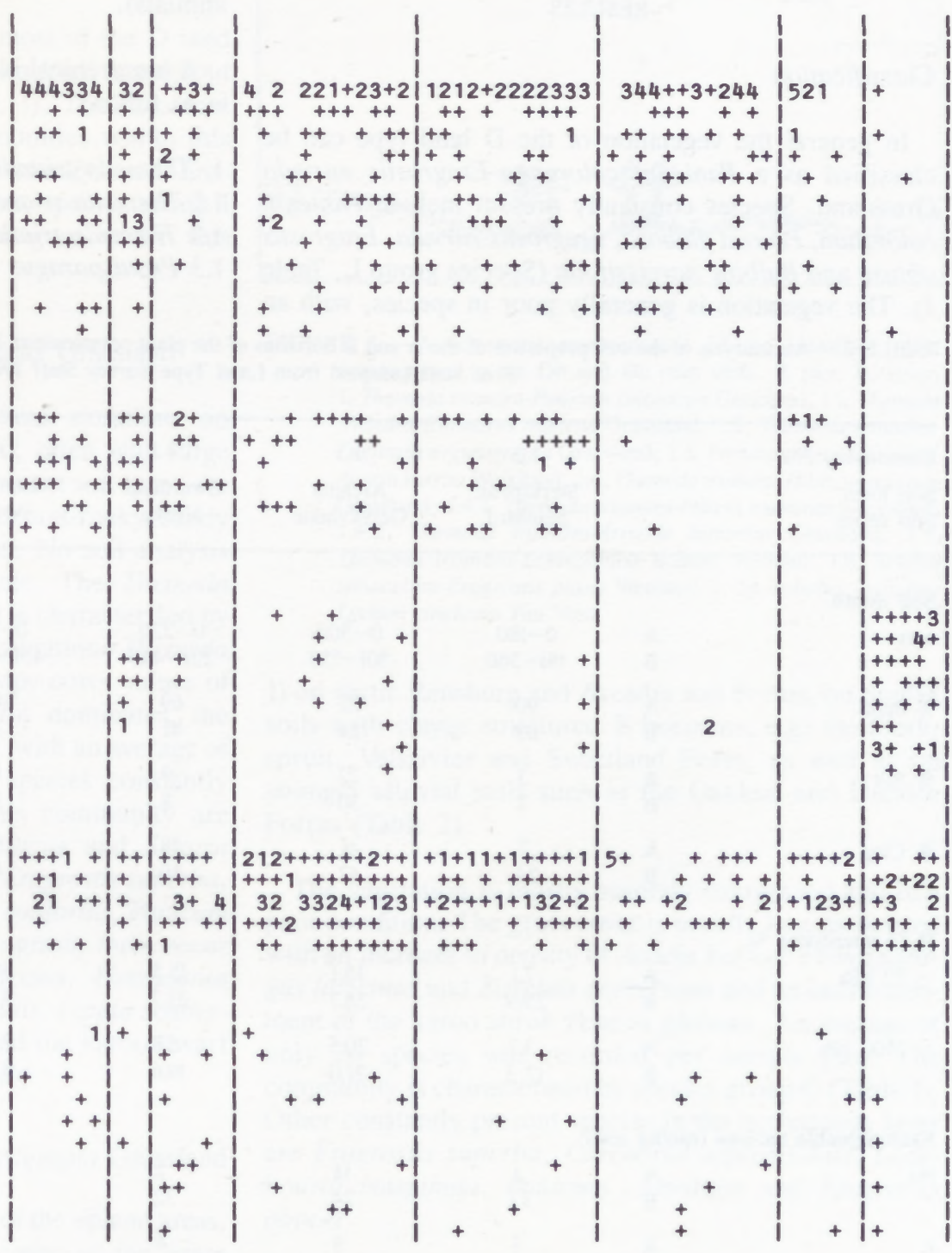

Species with an occurrence of $<4$ are omitted.

geology in these areas consists of Ecca shale, sandstone and grit. In the vicinity of Kroonstad mudstone, shale and sandstone of the Adelaide Supergroup are predominant, with dolerite sills occurring here and there (Land Type Survey Staff 1984).

\section{METHODS}

Relevés were compiled in 59 stratified random sample plots. As geology and land type are relatively uniform, stratification was based on terrain units (De Beer 1988; Land Type Survey Staff 1984). In accordance with Scheepers (1975), plot sizes were fixed at $16 \mathrm{~m}^{2}$ for grassland vegetation, while $100 \mathrm{~m}^{2}$ plots were used for woody vegetation (Bredenkamp \& Theron 1978). In each sample plot total floristic composition, using the BraunBlanquet cover-abundance scale (Mueller-Dombois \& Ellenberg 1974) was noted. Taxon names generally conform to those of Gibbs Russell et al. (1985 \& 1987), however, in accordance with Bredenkamp, Joubert \& Bezuidenhout (1989), Setaria flabellata Stapf and $S$. sphacelata (Schumach.) Moss were treated as separate species. Environmental data included identification of terrain types, soil types and estimation of aspect, slope and rockiness of the soil surface. Other soil properties were obtained from Land Type Survey Staff (1984), Table 2.

Two way indicator species analysis (TWINSPAN) (Hill 1979b) was applied to the floristic data set in order 
to derive a first approximation of the vegetation types of the area. Refinement of this classification was done by the application of Braun-Blanquet procedures (Behr \& Bredenkamp 1988; Bredenkamp, Joubert \& Bezuidenhout 1989). The resuits are presented in a phytosociological table (Table 1). In order to determine probable vegetation gradients, an ordination algorithm, Detrended Correspondence Analysis (DECORANA) (Hill 1979a) was applied to the floristic data set.

\section{RESULTS}

\section{Classification}

In general the vegetation of the D land type can be classified as a Panicum coloratum-Eragrostis curvula Grassland. Species constantly present include Panicum coloratum, Pentzia globosa, Eragrostis curnula, Eragrostis obtusa and Bulbine narcissifolia (Species group L. Table $1)$. The vegetation is generally poor in species, with an average of 20 species per sample plot. The vegetation shows some similarity to certain bottomland communities described by Scheepers (1975). Direct comparisons are, however, difficult due to the differences in techniques applied and also due to differences in the scale of the surveys.

The greater part of the vegetation is utilized as pasture for sheep. The vegetation varies as a result of habitat variations, for example in the topography, soil type, drainage regime and vegetation management (grazing by animals).

A hierarchical classification of the plant communities is as follows:

1. Themeda triandra-Panicum coloratum Grassland 1.1 Themeda triandra-Elionurus muticus Grassland 1.2 Themeda triandra-Digitaria argyrograpta Grassland 1.3 Protasparagus laricinus-Acacia karroo Woodland

TABLE 2. - An analysis of the soil properties of the A and B horizons of the plant communities in the D land type of the north-western Orange Free State (adapted from Land Type Survey Staff 1984)

\begin{tabular}{|c|c|c|c|c|c|c|}
\hline Community No. & 1.2 & 1.3 & 1.4 .1 & 1.4 .2 & 1.6 & 2 \\
\hline $\begin{array}{l}\text { Soil form } \\
\text { Soil series }\end{array}$ & $\begin{array}{l}\text { Sterkspruit } \\
\text { Stanford }\end{array}$ & $\begin{array}{c}\text { Arcadia } \\
\text { Gelykvlakte }\end{array}$ & $\begin{array}{c}\text { Swartland } \\
\text { Nyoka }\end{array}$ & $\begin{array}{l}\text { Bonheim } \\
\text { Weenen }\end{array}$ & $\begin{array}{l}\text { Bonheim } \\
\text { Weenen }\end{array}$ & $\begin{array}{c}\text { Arcadia } \\
\text { Gelykvlakte }\end{array}$ \\
\hline
\end{tabular}

\section{Soil depth}

\% Sand

$\begin{array}{ll}\text { A } & 0-180 \\ \text { B } & \end{array}$

$\%$ Silt

$$
\text { A }
$$$$
181-360
$$

$0-5(x)$

$0-220$

$221-440$

$0-450$

451-1 200

$0-450$
$451-800$

$0-700$

69

41

69

32
24

22

30

9

8

18

\% Clay

$\mathrm{H}_{2} \mathrm{O}$ retentivity \%

$-33 \mathrm{kPa}$
$-1500 \mathrm{kPa}$

Exchangeable cations (me/kg soil)

$\begin{array}{lrrr}\mathrm{Na} & \mathrm{A} & 1 & 1 \\ & \mathrm{~B} & 32 & 2 \\ \mathrm{~K} & \mathrm{~A} & 3 & \\ & \mathrm{~B} & 2 & 14 \\ \mathrm{Ca} & \mathrm{A} & 20 & 18 \\ & \mathrm{~B} & 61 & 7 \\ \mathrm{Mg} & \mathrm{A} & 12 & 10 \\ & \mathrm{~B} & 58 & 23 \\ \text { Total } & \mathrm{A} & 36 & 31 \\ & \mathrm{~B} & 135 & \end{array}$

$\begin{array}{rr}14 & \\ 24 & 32 \\ 3 & \\ 0 & \\ 144 & 28 \\ 186 & 87 \\ 71 & 24 \\ 105 & 80 \\ 232 & 58 \\ 315 & 20\end{array}$

2
32
4
2
28
87
24
80
58
201

40
45
2
2
110
114
98
134
250
285

$\mathrm{pH}\left(\mathrm{H}_{2} \mathrm{O}\right)$

$\begin{array}{ll}\text { A } & 7 \\ \text { B } & 9\end{array}$

Resistance (ohm)

$\begin{array}{rrrrrrr}\text { A } & 3500 & 700 & 3100 & 280 & 1000 & 300 \\ \text { B } & 600 & 350 & 490 & 120 & 960 & 220\end{array}$


1.4 Themeda triandra-Hibiscus trionum Grassland 1.4.1 Themeda triandra-Felicia filifolia Grassland 1.4.2 Themeda triandra-Aristida bipartita Grassland 1.5 Themeda triandra-Echinochloa holubii Wetland 1.6 Setaria sphacelata-Eragrostis plana Wetland

2. Sporobolus ioclados-Lycium cinereum Pan Veld

\section{Description of communities}

\section{Themeda triandra-Panicum coloratum Grassland}

This major grassland type covers most of the D land type, excluding the pans which occur scattered throughout the area (Kooij et al. 1990: 234, fig. 1). The dominant species in almost all the plant communities within this major grassland type are Themeda triandra and Eragrostis curvula. Within the study area, species group I (Table 1) may be considered as diagnostic for this Grassland.

\subsection{Themeda triandra-Elionurus muticus Grassland}

This community is found in upland situations on relatively sandy and well drained soil, often with large exposed rocks (Figure 1). The predominant soil types are the Mispah and Glenrosa Forms and in non-rocky, sandy areas the deep (>1 200) Hutton Form. No soil analysis data on these soil types are available. The Themeda triandra-Elionurus muticus Grassland is characterised by species group A (Table 1). In typical situations Themeda triandra dominates entirely, with canopy cover values of up to $75 \%$. Where Themeda triandra dominates, the occurrence of other species is limited, with an average of 20 species per relevé. Other grass species constantly ( $>50 \%$ of the relevés) found in this community are the diagnostic species Elionurus muticus and Setaria sphacelata and also Aristida congesta, Eragrostis superba, Cymbopogon plurinodis, Heteropogon contortus, Panicum coloratum and Eragrostis curvula. Non-grassy forbs occur only scattered, but Commelina africana, Hermannia depressa, Salvia radula, Crabbea acaulis, Lippia scaberrima, Oxalis sp., Hibiscus pusillus and the karoo dwarf shrub Pentzia globosa occur constantly.

\subsection{Themeda triandra-Digitaria argyrograpta Grassland}

On slightly drier or overgrazed sites of the upland areas, the total cover, and especially the cover of the grass species, is less than in the general situation occupied by the Themeda triandra-Elionurus muticus Grassland. Although Themeda triandra is still dominant, Cymbopogon plurinodis is locally conspicuous. An average of 33 species was recorded per sample plot. This community is characterised by species group B (Table 1). Other species constantly present in the relevés representing the community, are the grasses Aristida congesta, Eragrostis superba, Heteropogon contortus, Panicum coloratum and the non-grassy forbs Commelina africana, Hibiscus pusillus and Albuca sp.

\subsection{Protasparagus laricinus-Acacia karroo Woodland}

This Woodland is a bottomland community which occurs along dry water courses or seasonal rivulets (Figure

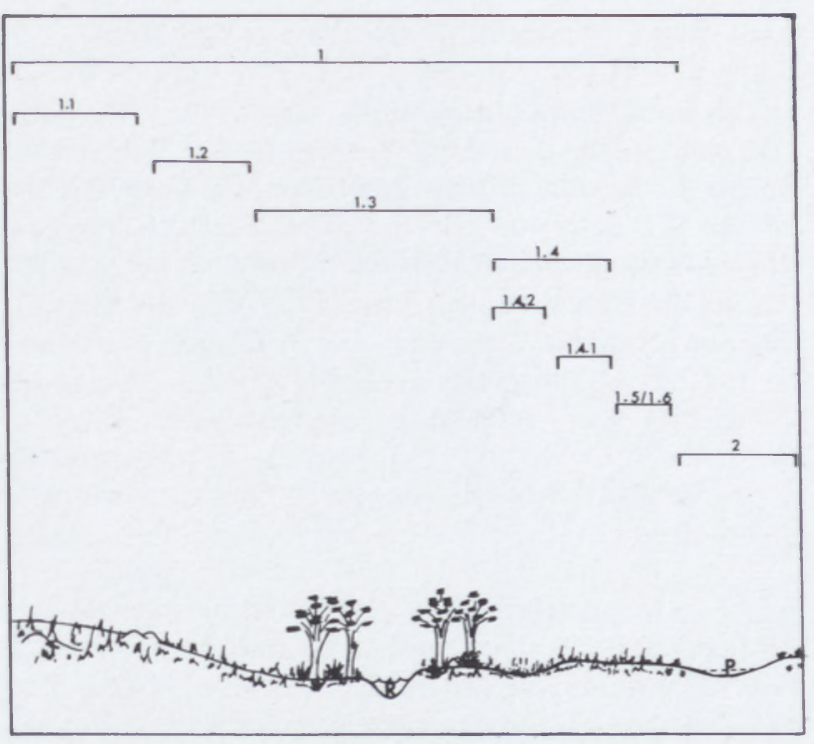

FIGURE 1.-A schematic representation of the identified plant communities in the $\mathrm{Db}$ and $\mathrm{Dc}$ map units. $\mathrm{P}$, pan; $\mathrm{R}$, river; 1, Themeda triandra-Panicum coloratum Grassland; 1.1, Themeda triandra-Elionurus muticus Grassland; 1.2, Themeda triandraDigitaria angyrograpta Grassland; 1.3, Protasparagus laricinusAcacia karroo Woodland; 1.4, Themeda triandra-Hibiscus trionum Grassland; 1.4.1. Themeda triandra-Felicia muricata Grassland; 1.4.2. Themeda triandra-Aristida bipartita Grassland; 1.5, Themeda triandra-Echinochloa holubii Wetland; 1.6, Setaria sphacelata-Eragrostis plana Wetland; 2, Sporobolus iocladosLycium cinereum Pan Veld.

1) on vertic Rensburg and Arcadia soil Forms, on duplex soils with clayey structured B horizons, e.g. the Sterkspruit, Valsrivier and Swartland Form, as well as on younger alluvial soils such as the Oakleaf and Dundee Forms (Table 2).

The vegetation is mostly severely overgrazed and in a poor condition. The grass cover is usually low, associated with an increase in density of Acacia karroo, Protasparagus laricinus and Ziziphus zeyheriana and an enchroachment of the karoo shrub Pentzia globosa. An average of only 26 species was recorded per sample plot. The community is characterised by species group C (Table 1). Other constantly present species in the herbaceous layer are Eragrostis superba, Corchorus asplenifolius, Ledebouria marginata, Panicum coloratum and Eragrostis obtusa.

\subsection{Themeda triandra-Hibiscus trionum Grassland}

The extensive flat plains of the D land type are typically covered by the Themeda triandra-Hibiscus trionum Grassland which represents the largest part of the Themeda triandra-Panicum coloratum Grassland (Figure 1). The vegetation is characierised by species group D (Table 1). An average of 20 species was recorded per sample plot. The vegetation is mostly dominated by Themeda triandra, Eragrostis curvula and Panicum coloratum, with the karoo dwarf shrub Pentzia globosa conspicuously present. Two distinct communities were identified, namely the Felicia filifolia-Themeda triandra Grassland on the relatively drier slightly raised sites, mostly on duplex soils, and the Aristida bipartita-Themeda triandra Grassland on vertic or near vertic soils of moist bottomland sites. 


\subsubsection{Themeda triandra-Felicia filifolia Grassland}

This community occurs on the slightly raised, extensive plains of the D land type (Figure 1). The Sterkspruit, Valsrivier, Swartland, Mayo and Hutton soil Forms (Table 2) are characteristic for the relatively well drained Themeda triandra-Felicia filifolia Grassland community and are therefore drier than those of the Aristida bipartitaThemeda triandra Grassland. The vegetation is characterised by species group E (Table 1). An average of 20 species was recorded per sample plot. Themeda triandra and Eragrostis curvula are mostly co-dominant. In overgrazed situations, however, Eragrostis curvula predominates.

The poor condition of the vegetation is indicated by the constant presence of the karroid shrubs Felicia filifolia and Pentzia globosa, and also pioneer species such as Hibiscus trionum, Aristida congesta, Cirsium vulgare, Tragus racemosus and Cynodon dactylon.

Other constantly present species include Eragrostis superba, Eragrostis obtusa, Corchorus asplenifolius, Cymbopogon plurinodis, Oxalis sp. and Ledebouria marginata.

\subsubsection{Themeda triandra-Aristida bipartita Grassland}

This Grassland is restricted to extensive bottomland plains and depressions, often on poorly drained and seasonally waterlogged vertic or near vertic soils (Figure 1). Soil types include the Arcadia, Rensburg. Willowbrook and Bonheim Form (Table 2). The vegetation is characterised by species group F (Table 1). Also of differential value is the simultaneous presence of the typical bottomland species Eragrostis plana and Setaria sphacelata and others (Species groups $\mathrm{H}$ and $\mathrm{J}$, Table 1). An average of 21 species was recorded per sample plot.

\subsection{Themeda triandra-Echinochloa holubii Wetland}

This grassland is restricted to the wet, marshy conditions often found in the bottomland situations of the Db map unit west of Kroonstad. Some relevés were also compiled at the edges of wet pans in the Wesselsbron area. No soil analysis data are available for this community.

The vegetation is characterised by species group $G$ (Table 1). Also of differential value is the occasional presence of species from species group $\mathrm{H}$. An average of 16 species was recorded per sample plot. Dominants are Themeda triandra and Eragrostis curvula; other constantly present species include Felicia muricata. Eragrostis superba, Cynodon dactylon, Oxalis sp., Commelina africana, Cirsium vulgare, Panicum coloratum, Eragrostis obtusa and Pentzia globosa.

\subsection{Setaria sphacelata-Eragrostis plana Wetland}

This community is restricted to seasonally waterlogged soils of the wet vley areas which are abundant in the D land type (Figure 1). Soil types include the Katspruit, Willowbrook and Bonheim Forms (Table 2).

The vegetation is characterised by the presence of species group $\mathrm{H}$ and the absence of species groups $\mathrm{F}$ and
$\mathrm{G}$ (Table 1). An average of 14 species was recorded per sample plot.

The most prominent species are the diagnostic Eragrostis plana and also Themeda triandra, Panicum coloratum and Eragrostis curvula. Other species often present are Setaria sphacelata, Aristida congesta, Cynodon dactylon and Cirsium vulgare.

\section{Sporobolus ioclados-Lycium cinereum Pan Veld}

This community is restricted to the sodic and calcareous soils on the fringes of the pans within the area (Figure 1). These areas are severely overgrazed and the vegetation is scanty and typically karroid. The Willowbrook, Rensburg, Arcadia and Inhoek soil Forms are typical of this community.

This community is characterised by species group $\mathrm{K}$ (Table 1). An average of 18 species was recorded per sample plot. The vegetation is dominated by the karroid dwarf shrubs Pentzia globosa. Lycium cinereum and Felicia filifolia. Other constantly present prominent species are Panicum coloratum, Eragrostis curvula and Eragrostis obtusa.

\section{Ordination}

The distribution of relevés along the first and second axes of the ordination is given in Figure 2.

In this scatter diagram only a slight discontinuity in the distribution of the relevés can be observed. However, the syntaxa are more or less restricted to specific areas in the scatter diagram. Four classes of discontinuity were distinguished, namely:

A, Protasparagus laricinus-Acacia karroo Woodland along riverbanks (community 1.3);

G, The Grassland communities (communities 1.1, 1.2, 1.4 and 1.5);

W. Setaria sphacelata-Eragrostis plana Wetland (community 1.6); and

P, Sporobolus ioclados-Lycium cinereum Panveld (community 2).

The vegetation gradient on the first axis may be associated with a moisture/trophic gradient, from the relatively wet, leached, distrophic conditions on the left to the relatively dry, eutrophic, sodic conditions on the right of the diagram. Grassland $(\mathrm{G})$ relevés are located to the left, whereas the relevés of the Sporobolus iocladosLycium cinereum Panveld (P) are located on the right of the scatter diagram. The Protasparagus laricinus-Acacia karroo (A) Woodland is situated in an intermediate position. The second axis represents a moisture gradient with the wet Setaria sphacelata-Eragrostis plana Wetland (W) at the top, the drier Grassland (G) and Woodland (W) towards the bottom of the scatter diagram.

In Figure 3 the portion of the scatter diagram representing the Grassland is enlarged. The relevés of communities 1.1, 1.2, 1.4.1, 1.4.2 and 1.5 are more or less restricted to specific areas in this enlarged scatter diagram. 


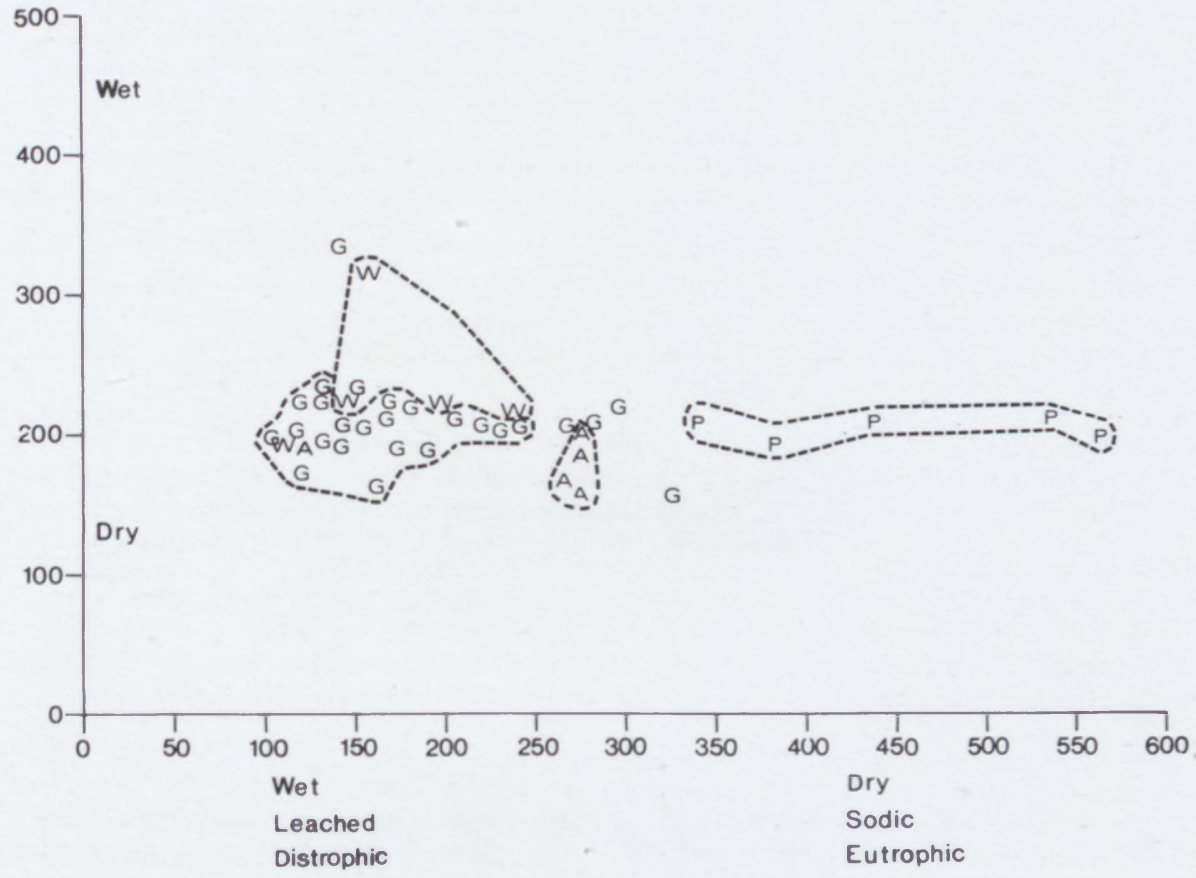

FIGURE 2.-A scatter diagram of the ordination of the vegetation on the D land type. A, Protasparagus laricinus-Acacia karroo Woodland community $1.3 ; \mathrm{G}$, Grassland communities; W, Setaria sphacelata-Eragrostis plana Wetland community 1.6 ; P, Sporobolus ioclados-Lycium cinereum Pan Veld community 2.

The vegetation gradient on the first axis, from community 1.5 , via community 1.4 .2 to community 1.4 .1 can be explained by the general habitat gradient indicated in Figure 2. The position of communities 1.1 and 1.2 to the left of communities 1.4.1, 1.4.2 and 1.5 cannot be explained. However, their positions along the second axis indicate a drier habitat.

\section{CONCLUSION}

The methodology of refining the results of a TWINSPAN classification by Braun-Blanquet procedures (Bredenkamp \& Behr 1988) was successfully applied in this study. The plant communities distinguished are considered to be ecologically interpretable, as they relate to specific environmental conditions.

The results of the ordination suggest vegetation gradients which correlate with the moisture and trophic regimes of the soil. The results of this study, complemented by an additional phytosociological study of the B land type, should form the basis of a phytosociological synthesis of the north-western Orange Free State.

\section{ACKNOWLEDGMENT}

This research was financially supported by the Foundation for Research Development, CSIR.

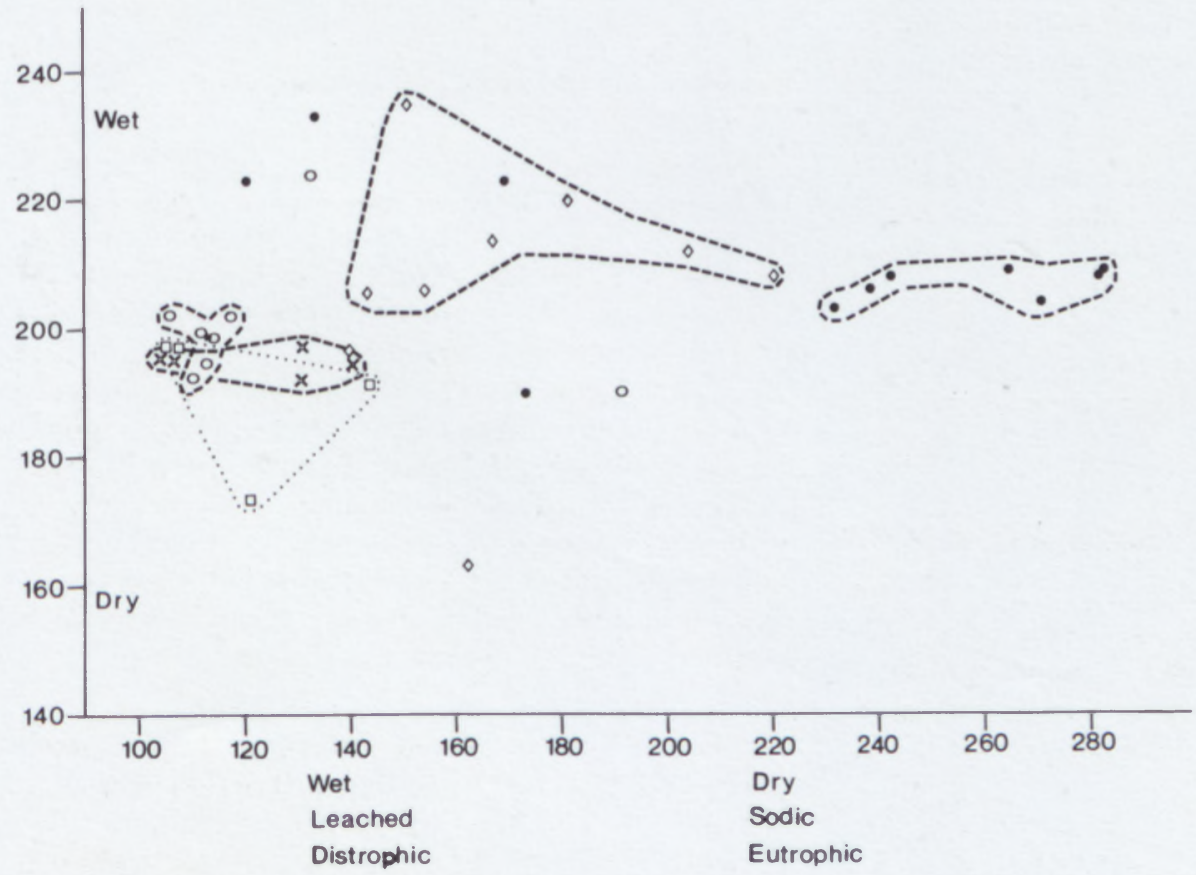

FIGURE 3.-An enlargement of a portion of the scatter diagram given in Figure 2. X, Themeda triandra-Elionurus muticus Grassland community 1.1; $\square$, Themeda triandra-Digitaria argyrograpta Grassland community $1.2 ;$. Themeda triandra-Felicia filifolia Grassland community $1.4 .1 ; \diamond$, Themeda triandra-Aristida bipartita Grassland 1.4.2; $\bigcirc$, Themeda triandra-Echinochloa holubii Grassland community 1.5 . 


\section{REFERENCES}

BEHR, C.M. \& BREDENKAMP, G.J. 1988. A phytosociological classification of the Witwatersrand National Botanical Garden. South African Journal of Botany 54: 525-533.

BREDENKAMP, G.J., JOUBERT, A.F. \& BEZUIDENHOUT, H. 1989. A reconnaissance survey of the vegetation of the plains in the Potchefstroom-Fochville-Parys area. South African Journal of Botany 55: 199-206.

BREDENKAMP. G.J. \& THERON, G.K. 1978. A synecological account of the Suikerbosrand Nature Reserve. 1. The phytosociology of the Witwatersrand geological system. Bothalia $12: 513-529$.

DE BEER, A.S. 1988. Plantspesievoorkeure van vleisbeeste in die Hoèveldstreek onder 'n stelsel van beheerde selektiew' beweiding. M.Sc. (Agric) thesis, University of Pretoria, Pretoria.

DU PREEZ, P.J. 1987. Ekologie van die boomgemeenskappe van die Vredefortistrik. M.Sc. thesis. University of the Orange Free State. Bloemfontein.

GIBBS RUSSELL, G.E., REID, C., VAN ROOYEN, J. \& SMOOK L. 1985. List of species of southern African plants, Edn 2, Part 1. Memoirs of the Botanical Surver of South Africa No. 51: 1-152.

GIBBS RUSSELL, G.E., WELMAN, W.G., RETIEF, E., IMMEL MAN, K.L., GERMISHUIZEN, G., PIENAAR, BJ., VAN WYK, M., NICHOLAS, A., DE WET, C., MOGFORD, JC \& MULVENNA, J. 1987. List of species of the southern African plants, Edn 2, Pan 2. Memoirs of the Botanical Survey of South Africa No. 56: 1-270.

HILL, M.O. 1979a. DECORANA-a FORTRAN program for detrended correspondence analysis and reciprocal averaging. Cornel]
University, Ithaca, New York.

HILL. M.O. 1979b. TWINSPAN - a FORTRAN program for arranging multivariate data in an ordered two wav table by classification of the individuals and attributes. Cornell University, Ithaca, New York

KOOIJ, M.S., BREDENKAMP. G.J. \& THERON, G.K. 1990. A phytosociological survey of the vegetation of the north-western Orange Free State. 1. The physical environment. Bothalia 20: $233-240$.

LAND TYPE SURVEY STAFF 1984. Land types of the maps 2626 West-Rand, 2726 Kroonstad. Memoirs on the Agricultural Notural Resources of South Africa No. 4: 1-441

MACVICAR, C.N., LOXTON, R.F., LAMBRECHTS, J.J.N., LE ROUX, J., DE VILLIERS. J.M., VERSTER, E., MERRYWEATHER. F.R. VAN ROOYEN, T.H. \& HARMSE, H.J. VON M. 1977. Grondklassifikasie, 'n binomiese sisteem vir SuidAfrika. Departement Landbou-Tegniese Dienste. Pretoria.

MENTIS, M.T. \& HUNTLEY, B.J. 1982. A description of the Grassland Biome Project. Co-operative Scientific Programme Council for Scientific and Industrial Research, Report No. 62. CSIR, Pretoria.

MUELLER-DOMBOIS, D. \& ELLENBERG, H. 1974. Aims and methods of vegetation ecology. Wiley. New York

SCHEEPERS, J.C. 1975. The plant ecology of the Kroonstad and Bethlehem areas of the Highveld Agricultural Region. D.Sc. dissertation, University of Pretoria, Pretoria

SCHEEPERS. J.C. 1986. Grassland Biome Project: proceedings of the workshop on the classification and mapping. Ecosystems Programmes Occasional Report Series No. 16. CSIR, Pretoria. 